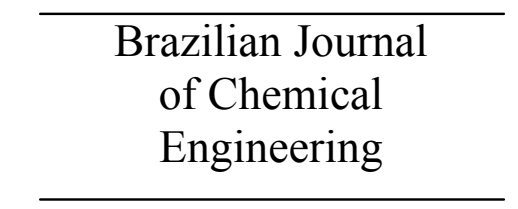

ISSN 0104-6632

Printed in Brazil

www.abeq.org.br/bjche

Vol. 27, No. 02, pp. 227 - 242, April - June, 2010

\title{
A REVIEW ON CARBON NANOTUBES IN AN ENVIRONMENTAL PROTECTION AND GREEN ENGINEERING PERSPECTIVE
}

\author{
Yit Thai Ong, Abdul Latif Ahmad, Sharif Hussein Sharif Zein and Soon Huat Tan* \\ School of Chemical Engineering, Engineering Campus, Phone: +60-4-599-6475, Fax: +60-4-594-1013, \\ Universiti Sains Malaysia, Seri Ampangan, 14300, Nibong Tebal, SPS, Pulau Pinang, Malaysia. \\ E-mail: chshtan@eng.usm.my \\ (Submitted: November 19, 2009 ; Revised: February 20, 2010 ; Accepted: March 21, 2010)
}

\begin{abstract}
Recent developments in nanotechnologies have helped to benchmark carbon nanotubes (CNTs) as one of the most studied nanomaterials. By taking advantages of CNTs extraordinary physical, chemical and electronic properties, a wide variety of applications has been proposed in various engineering fields. In this short review, the contribution of CNTs is addressed in terms of sustainable environment and green technologies perspective, such as waste water treatment, air pollution monitoring, biotechnologies, renewable energy technologies, supercapacitors and green nanocomposites. Consideration of CNTs for large scale application from the aspect of cost and potential hazards are also discussed. Based on the literature studied, CNTs pose a great potential as a promising material for application in various environmental fields.
\end{abstract}

Keywords: Carbon nanotubes; Environment; Waste water treatment; Air pollution monitoring; Biotechnologies; Renewable energy; Supercapacitors.

\section{INTRODUCTION}

Since the discovery of carbon nanotubes (CNTs), they have eventually revolutionized the future nanotechnologies area. CNTs as reported by Iijima (1991) and Bethune et al. (1993), are seamless cylinder-shaped macromolecules with a radius as small as a few nanometers, and up to several micrometers in length. The walls of these tubes are constructed of a hexagonal lattice of carbon atoms and capped by fullerene-like structures. The unique structure of CNTs can be divided mainly into multiwalled carbon nanotubes (MWCNTs) and singlewalled carbon nanotubes (SWCNTs). MWCNTs are composed of two or more concentric cylindrical shells of graphene sheets coaxially arranged around a central hollow area with spacing between the layers. In contrast, SWCNTs are made of a single cylinder graphite sheet held together by van der Waals bonds (Balasubramanian and Burghard, 2005; Daniel et al., 2007). Current synthesis techniques including electric arc discharge (Journet et al., 1997), laser ablation (Guo et al., 1995) and chemical vapor decomposition (CVD) (Dai et al., 1996) are used commercially to produce large quantities of CNTs.

CNTs mutable hybridization states and sensitivity of the structure to perturbations in synthesis conditions exploit their unique physical, chemical and electronic properties (as stated in Table 1) which inspire innovation in new technologies and applications. Moreover, these unique and tunable properties offer potential advances in environmental systems from proactive (prevention of environmental degradation, optimizing energy efficiency) to retroactive (waste water reuse, pollutant transformation) (Mauter and Elimelech, 2008).

In this short review, current applications of CNTs in waste water treatment, air pollution monitoring, biotechnology, renewable energy and supercapacitors are explored and a proposal for green nanocomposite design that embraces the $3 R$ (reduce, reuse and recycle) concept has also been discussed. At the end, consideration of CNTs in large scale applications is surveyed from the aspect of cost and potential hazards.

*To whom correspondence should be addressed 
Table 1: Theoretical and experimental properties of CNTs (Xie et al., 2005)

\begin{tabular}{|c|c|c|}
\hline Properties & SWCNTs & MWCNTs \\
\hline Specific Gravity & $0.8 \mathrm{~g} / \mathrm{cm}^{3}$ & $1.8 \mathrm{~g} / \mathrm{cm}^{3}$ \\
\hline Elastic Modulus & $\sim 1 \mathrm{TPa}$ & $\sim 0.3-1 \mathrm{TPa}$ \\
\hline Strength & $50-500 \mathrm{GPa}$ & $10-60 \mathrm{GPa}$ \\
\hline Resistivity & $5-50 \mu \Omega \mathrm{cm}$ & $5-50 \mu \Omega \mathrm{cm}$ \\
\hline Thermal Conductivity & $3000 \mathrm{~W} \mathrm{~m}^{-1} \mathrm{~K}^{-1}$ & $3000 \mathrm{~W} \mathrm{~m}^{-1} \mathrm{~K}^{-1}$ \\
\hline Thermal Stability & $>700^{\circ} \mathrm{C}$ (in air) & $>700^{\circ} \mathrm{C}$ (in air) \\
\hline & $2800^{\circ} \mathrm{C}$ (in vacuum) & $2800^{\circ} \mathrm{C}$ (in vacuum) \\
\hline Specific Surface Area & $\sim 400-900 \mathrm{~m}^{2} / \mathrm{g}$ & $\sim 200-400 \mathrm{~m}^{2} / \mathrm{g}$ \\
\hline
\end{tabular}

\section{Carbon Nanotubes in Waste Water Treatment}

Waste water discharge from domestic, industrial or agricultural sources encompasses a wide range of contaminants and has drawn major concern worldwide since they adversely affect the quality of water. The contaminants found in waste water, such as heavy metal ions ( $\mathrm{Li}$ et al., 2002; Lu and Chiu, 2006; Türker, 2007; Hsieh and Horng, 2007; Rao et al., 2007; Liu et al., 2008; Lu and Chiu, 2008; Lu et al., 2008; Stafiej and Pyrzynska, 2008; Xu et al., 2008; Gao et al., 2009), 1,2-dichlorobenzene (Lin et al., 2002; Peng et al., 2003) and dioxin (Long and Yang, 2001; Fagan et al., 2007) are non-degradable, highly toxic and carcinogenic and can result in accumulative poisoning, cancer and nervous system damage. Removal of these contaminants relies on the sorption behavior of a sorbent. CNTs, with their high surface active site to volume ratio and controlled pore size distribution, have an exceptional sorption capability and high sorption efficiency compared to conventional granular and powder activated carbon, which have intrinsic limitations like surface active sites and the activation energy of sorption. Extensively studies found that the adsorption capacity of CNTs depends on both the surface functional groups and the nature of the sorbate. For instance, the amounts of surface acidity (carboxylic, lactonic and phenolic groups) favor the adsorption of polar compounds (Rao et al., 2007). On the other hand, the unfunctionalized CNTs surface is proved to have higher adsorption capacity towards non-polar compounds such as polycyclic aromatic hydrocarbons (Yang et al., 2006b; Wang et al., 2008). The sorption behaviors of CNTs mainly involve chemical interaction for polar compounds and physical interaction for non-polar compounds. The sorption of both polar and non-polar compounds is normally fitted with Langmuir or Freundlich isotherms (Long and Yang, 2001; Li et al., 2002; Peng et al., 2003; Lu and Chiu, 2006; Yang et al., 2006b; Lu et al., 2008; Xu et al., 2008).
Sorption capacity of CNTs is effective over a broad $\mathrm{pH}$ range. Particularly, optimum performance was reported in the $\mathrm{pH}$ range of 7 to 10 (Rao et al., 2007). Other than this $\mathrm{pH}$ range, ionization and competition between ionic species could occur (Boehm, 2002; Weng and Huang, 2004; Lu and Chiu, 2006; Stafiej and Pyrzynska, 2008). Although CNTs are more expensive compare to conventional activated carbon, their sorption and desorption cycles are more efficient than conventional activated carbon. Sorption/desorption studies have shown the availability performance of CNTs under a numbers of sorption and desorption cycles (Rao et al., 2007; $\mathrm{Lu}$ et al., 2008). A regeneration study performed by $\mathrm{Lu}$ et al. (2008) reported that the adsorption and desorption of $\mathrm{Ni}^{2+}$ in CNTs slightly decreased, but those of granular activated carbon (GAC) sharply decreased after a number of cycles. This phenomenon could be explained by the fact that the porous structure of GAC make desorption of $\mathrm{Ni}^{2+}$ more difficult as the ions have to move from the inner surface to the external surface of the pores.

In addition to serving as sorbent for organic and inorganic contaminants, current technology has used CNTs as nanofilters to reduce particle concentrations in waste water (Srivastava et al., 2004; Jin et al., 2007; Tahaikt et al., 2007). Similar to sorbents, specific selectivity on CNTs filters can be manipulated through the attachment of different functionalities at the pore entrances (Fornasiero et al., 2008). Despite their hydrophobic characteristics, CNTs have shown an extraordinary performance in transporting water. Molecular dynamics simulations indicate that the hydrophobic nature of CNTs pores creates weak interactions with water molecules, thus enabling a fast and nearly frictionless flow of water (Noy et al., 2007). Another explanation from Hummer et al. (2001) is that the frictionless flow of water is attributed to the nanoscale confinement that leads to narrowing of the interaction energy distribution, and minimizes the interaction with water. Apart from that, recent filtration studies using 
CNTs have also revealed the capability of CNT nanofilters to remove pathogenic microorganisms such as protozoa, bacteria and viruses in waste water treatment, with microorganisms being retained on the surface of CNT based on a depth-filtration mechanism (Bohonak and Zydney, 2005; Mostafavi et al., 2009). Brady-Estévez et al. (2008) reported an effective way to remove $E$. coli bacteria at low pressure using SWCNT filters. As covering on a poly(vinylidene fluoride) (PVDF) based microporous membrane, nanotube bundles inside the SWCNTs were able to completely capture and retain E. coli cells. A modification through immobilization of SWCNTs on a microporous ceramic filter was also proposed to further enhance robustness, reusability and thermal resistance of the filter without sacrificing its performance. In another study, Mostafavi et al. (2009) synthesized a controllable nanoscale porosity CNTbased filter by using a spray pyrolysis method and observed a maximum efficiency in removal of MS2 virus at a pressure of 8-11 bar.

Application of CNTs in waste water treatment is not limited to filtration and sorbent; several researchers observed strong antimicrobial properties of CNTs. Such behavior allows CNTs to replace chemical disinfectants as a new effective way to control microbial pathogens (Savage and Diallo, 2005; Kang et al., 2007; Li et al., 2008a; Nepal et al., 2008; Cortes et al., 2009). Applying CNTs in water disinfection treatment avoids the formation of harmful disinfection byproducts (DBPs) such as trihalomethanes, haloacetic acids and aldehydes, because they are not strong oxidants and are relatively inert in water. In order to facilitate their dispersion, surfactant or polymers like sodium dodecyl benzenesulfonate, polyvinylpyrolidone or Triton-X are generally used. Highly purified CNTs exhibit strong antimicrobial activity toward Gram positive and Gram negative bacteria, as well as bacterial spores. The activities inflicted by the antimicrobial property can be attributed to impairment of pathogen cellular function by destruction of major constituents (e.g., cell wall), interference with the pathogen cellular metabolic processes, and inhibition of pathogen growth by blockage of the synthesis of key cellular constituents (e.g., DNA, coenzymes and cell wall proteins). Kang et al. (2007) confirmed the strong antimicrobial activities of SWCNT; direct contact of $E$. coli cell with SWCNTs leads to severe membrane damage and subsequent cell inactivation. Some studies have also proposed CNTs as scaffolding for antimicrobial agents like Ag nanoparticles (Morones et al., 2005; Yuan et al., 2008) and antimicrobial lysozyme
(Nepal et al., 2008) due to their excellent mechanical properties.

\section{Carbon Nanotubes in Air Pollution}

The outstanding electrical, electrochemical and optical properties of CNTs aroused the interest of researchers to explore the potential applications of CNTs as sensing elements to detect and monitor the concentration of toxic gases released in the environment (Wei et al., 2006; Van Hieu et al., 2008; Bondavalli et al., 2009; Di Francia et al., 2009; Lu et al., 2009; Penza et al., 2009a; Penza et al., 2009b; Zhang and Zhang, 2009). CNTs possess an unique and tunable electronic properties whereby their metallic or semi-conductivity is greatly influenced by their one dimensional cylindrical structure, such as size and chirality. CNT-based gas sensors offer a number of advantages over conventional metal oxide semi-conductor gas sensors including low power consumption, low operating temperature, and high sensitivity (Endo et al., 2008). An example of a CNT-based gas sensor is shown in Fig. 1. A thin film array of CNTs acts as a cathode and is separated from an aluminum anode by a 180 micron-thick glass insulator. The individual CNTs create a high electric field near their ultra-fine tips and increase the overall field to speed up the gas ionization process (Bogue, 2004). The detection by this gas sensor is based on the changes of resistance or conductance in CNTs as a result of direct contact with gas.

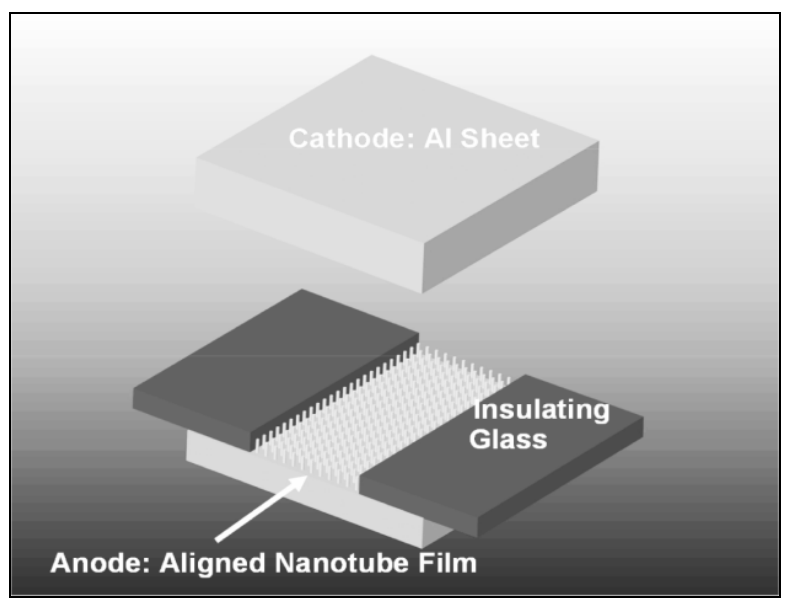

Figure 1: Schematic of a CNT-based gas sensor. Reprinted from Sensor Review, Vol. 24, Bogue, R. W., Nanotechnology: what are the prospects for sensors, Pages No. 253-260, (2004) with permission from (C) Emerald Group Publishing Limited all rights reserved. 
CNT-based gas sensors have been used in several researches for detection of nitrogen oxides (NOx) (Ueda et al., 2008a; Ueda et al., 2008b), nitrogen dioxide $\left(\mathrm{NO}_{2}\right)$ (Kong et al., 2000; Cantalini et al., 2003; Valentini et al., 2004; Cho et al., 2006; Moon et al., 2008), ammonia $\left(\mathrm{NH}_{3}\right)$ (Nguyen and Huh, 2006; Quang et al., 2006; Nguyen et al., 2007), and sulfur dioxide $\left(\mathrm{SO}_{2}\right)$ (Suehiro et al., 2005) at room temperature. Although the results showed high and prompt response from the gas sensors, the time consuming recovery represents a challenge. In order to improve gas desorption from the sensor, several strategies have been proposed. For instance, heating the sensor by using ultraviolet (UV) illumination and increasing the flux rate of purging gas can improve gas desorption from the sensor. Efforts have also been made to improve the sensitivity and affinity of CNTbased gas sensors through polymer functionalization (Wei et al., 2006; Lu et al., 2009). Incorporation of CNTs in conducting polymers such as polyaniline and polypyrrole leads to an increase in sensitivity of the sensor toward selected gases or vapors. A study of polymer coating by Qi et al. (2003) reported that a CNT-based gas sensor coated with polyethyleneimine (PEI) showed high affinity for $\mathrm{NO}_{2}$ detection at concentrations less than $1 \mathrm{ppb}$ without interference from $\mathrm{NH}_{3}$ due to the low binding affinity and sticking coefficient of $\mathrm{NH}_{3}$ on the electron-rich CNTs. Contrary to the PEI coated sensor, a CNT-based gas sensor coated with Nafion (a polymeric perfluorinated sulfonic acid ionomer) allowed higher selectivity for sensing $\mathrm{NH}_{3}$ owing to the blocking of $\mathrm{NO}_{2}$ on CNTs. Fabrication of a compact wireless gas sensor based on a CNT/poly(methyl methacrylate) (PMMA) composite chemiresistor by Abraham et al. (2004) also showed an improvement in sensitivity upon exposure to volatile organic compounds likes dichloromethane, chloroform and acetone vapor. Even though CNT-based gas sensors exhibit strong competition for conventional metal oxide sensors, non-stop developments have been carried out to improve the conventional gas sensor. An incorporation of CNTs in metal oxide sensors has been found to overcome the limitation of high operating temperature (Wei et al., 2004; Espinosa et al., 2007; Hoa et al., 2007; Van Duy et al., 2008; Van Hieu et al., 2008; Wang et al., 2008). Moreover, significant improvement in sensitivity and response time was observed in $\mathrm{CNT} /$ metal oxide sensors for detection of pollutant gasses such as $\mathrm{NO}_{2}$, and $\mathrm{NH}_{3}$ at room temperature. The enhanced performance was attributed to the effective accessing of nanopassages by the gas and the variation in conductance upon adsorption of the gas provided by CNTs (Hoa et al., 2007; Gong et al., 2008).

\section{Carbon Nanotubes in Biotechnology}

Owing to the increasing demand for innovative, environmental friendly technologies, there has been a rapid growth in biotechnology in recent years in which living organism are utilized to make products or processes for specific uses. The emergence of biotechnology provides an opportunity for the participation of CNTs, especially in biological fuel cells (biofuel cells). Biofuel cells, as defined by Palmore and Whitesides (1994), are fuel cells that rely on biocatalytic activity to generate electricity. Generally, they can be classified as microbial fuel cells (MFC) or enzymatic biofuel cells (EFC).

MFC exploit microbial catabolic activities to generate electric power. They have been considered as future options in waste water treatment since a variety of materials, including complex organic waste and renewable biomass in waste water, can be used as source materials (Logan et al., 2006; Watanabe, 2008). However, the technology is not feasible practically, primarily due to low performance and lack of technical maturity. Intensive work has been focused on employing and modifying CNTs as electrodes to increase power production in MFC because of their high conductivity and large surface area (Morozan et al., 2007; Qiao et al., 2007; Sharma et al., 2008; Tsai et al., 2009). Tsai et al. (2009) prepared a new type of electrode architecture by coating CNTs onto a carbon cloth to form a highly conductive electrode with high specific surface-area in MFC. The presence of CNTs resulted in an improvement of $250 \%$ in the power density compared with a nonCNT coated electrode. Sharma et al. (2008) compared the performance of MFC based on the CNT electrode against a plain graphite electrode; the CNT electrode showed an increment of approximately 6-fold in power density compared to the graphite electrode. Further optimization of the power density can be obtained by utilizing the biocompatibility of CNTs with microorganisms in MFC. Although CNTs were claimed to exhibit antimicrobial capability as discussed previously, the cytotoxicity behavior decreases after their modification and functionalization (Sayes et al., 2006). Investigation of the biocompatibility of Staphylococcus aureus with CNTs by Morozan et al. (2007) showed rapid microorganism growth in CNTmodified cell culture media. This points to the potential of reducing the loss of power generation if applied to MFC anodic design.

On the other hand, instead of microbial catalytic activities, EFC utilize enzyme or protein catalysis to 
convert chemical energy into electrical energy. So far, the application of EFC as power source for low power sensors, communication devices and medical implants has been hampered by their short lifetime, poor enzyme stability and low power density (Kim et al., 2006; Minteer et al., 2007). Nonetheless, the introduction of CNTs as bioelectrodes constitutes a major breakthrough in EFC. Other than mediating charge transfer, CNTs have manifested great efficiency in EFC by supplying a strong platform for enzyme immobilization (Fischback et al., 2006; Asuri et al., 2007; Li et al., 2008b; Zhao et al., 2009; Zhou et al., 2009). CNTs allowed enzyme molecules to be covalently attached onto their surface and promote high enzyme loading by permitting crosslinked enzyme aggregate coating (Fischback et al., 2006). In addition, the nanoscale environment provided by CNTs could enhance enzyme stability. Enzymes covalently attached onto CNTs were found to have a high degree of stability due to their covalent linkage, which afforded significant resistance against denaturation (Govardhan, 1999; Asuri et al., 2007; Sheldon, 2007). In another point of view, the curvature of CNTs increases the distance between enzyme molecules, thereby reducing detrimental interaction between the enzymes and leading to an increased enzyme stability (Asuri et al., 2006). The enzyme stability in EFC is important as it offers an excellent operational stability, which is anticipated to pave the way for increasing the power density and prolonging the lifetime of EFC. For instance, the stabilized activity of glucose oxidase coated on CNTs enabled the continuous operation of an EFC for more than 16 hours (Fischback et al., 2006).

\section{Carbon Nanotubes in Renewable Energy}

Worldwide consumption of marketed energy is anticipated to increase by $57 \%$ between 2004 and 2030 (International Energy Outlook, 2007). This phenomenon foresees the requirement for advance renewable energy source technologies in order to meet the long term energy demand challenge and protect the environmental balance.

The major breakthrough contributed by CNTs in the solar energy sector lies in their application in photovoltaic devices. Photovoltaic devices generate electricity through conversion of photons absorbed from the sun. To date, several drawbacks, including high cost and low stability under illumination, have been found for commercially available silicon and semiconductor-based photovoltaic devices (Aberle,
2000; Green, 2002). Therefore, CNTs are sought as an alternative material in various solar cell architectures, especially in silicon-based solar cells, organic solar cells, and dye-sensitized solar cells (as illustrated in Fig. 2), due to their affordability and remarkable energy conversion. The nanoscale active surface area of CNTs also allows massive photon absorption for harvesting solar energy, while the presence of a delocalized $\pi$-electron system increases the mobility of the charge transfer (Kamat, 2007; Scarselli et al., 2009). Good alignment between CNTs can further enhance their photoconductivity upon illumination. (Liu et al., 2009b).

Silicon-based solar cells utilize the simplest $\mathrm{p}-\mathrm{n}$ junction to separate electrons/holes and create current upon illumination. CNTs, when incorporated into silicon, serve as a heterojunction component for charge separation, as a highly conductive percolated network for charge transport, and as a transparent electrode for light illumination and charge collection (Khatri et al., 2009; Zhu et al., 2009). Therefore, modest cell efficiency with improvement in stability was observed in CNT/Si heterojunctions (Jia et al., 2008; Liang and Roth, 2008).

As a consequence of being flexible and having low production costs compared with silicon based solar cells, the development of organic solar cells has attracted a great deal of interest from researchers. Organic solar cells depend on a conductive organic polymer like poly(3-octylthiophene) (P3OT), poly(3hexylthiophene) (P3HT) or [6,6]-phenyl- $\mathrm{C}_{61}$-butyric acid methyl ester (PCBM) for light absorption and charge transfer (Janssen et al., 2005). Current research shows an improvement in efficiency upon incorporation of CNTs in the top electrode (Pasquier et al., 2005; Ulbricht et al., 2006), the photoactive layer (Landi et al.,2005) and the back electrode (Rowell et al., 2006; Ulbricht et al., 2007) of organic solar cells. In the photoactive layer, CNTs serve as photoactive material and optimize the performance of the cells by providing efficient hole or electron transport at the CNT/polymer interface. The photoactive component constructed with $\mathrm{P} 3 \mathrm{OT} / \mathrm{CNT}$ showed a higher open circuit voltage by taking advantage of the high electron transport capability of CNTs (Landi et al., 2005). In the top and back electrodes, CNTs manage to provide a large surface area for high optical transmittance and low sheet resistance to minimize power loss. Therefore, an increase in photocurrent was observed for the design of a top electrode composed of CNT films and Indium-tin oxide (ITO) (Pasquier et al., 2005; Ulbricht et al., 2006). 


\begin{tabular}{|c|}
\hline Top electrode \\
\hline $\mathrm{p}-\mathrm{C}(\mathrm{n}-\mathrm{C})$ \\
\hline $\mathrm{n}-\mathrm{Si}(\mathrm{p}-\mathrm{Si})$ \\
\hline Back electrode \\
\hline
\end{tabular}

(a)

\begin{tabular}{|c|}
\hline Top electrode \\
\hline $\begin{array}{c}\text { Photoactive layer } \\
\text { (P3HT/P3OT:PCBM) }\end{array}$ \\
\hline Back electrode \\
PEDOT:PSS/ITO \\
\hline
\end{tabular}

(b)

\begin{tabular}{|c|}
\hline Window electrode \\
\hline Photoelectrode/Dye \\
\hline Electrolyte \\
\hline Counter electrode \\
\hline
\end{tabular}

(c)

Figure 2: Basic solar cell architectures: (a) silicon-based solar cell, (b) organic solar cell and (c) dyesensitized solar cell. Reprinted from Solar Energy Materials and Solar Cells, Vol. 93, Zhu, H., Wei, J., Wang, K. and Wu, D., Applications of carbon materials in photovoltaic solar cells, Pages No. 1461-1470, (2009), with permission from Elsevier.

Dye-sensitized solar cells (DSSC) have been hailed as the promising solar cell for their low cost and simple preparation (O'Regan and Grätzel, 1991; Grätzel, 2003). Electricity is produced in DSSC when semiconducting materials create an electronhole pair and transfer the charge through a circuit to a counter electrode in contact with a redox couple in the electrolyte solution (Mills and Le Hunte, 1997). Applying CNTs as photoelectrode can help to increase the mobility of carrier transport upon exposure to visible light. However, direct use of CNTs as photoelectrodes could result in modest efficiency due to ultrafast recombination of photogenerated charge carriers. Hence, Brown et al. (2008) suggested $\mathrm{CNT} / \mathrm{TiO}_{2}$ as a strategy to improve charge separation and promote charge flow since $\mathrm{TiO}_{2}$ particles present on CNTs are capable of injecting electrons from their excited state. Besides photoelectrodes, CNTs are also a popular choice of materials for DSSC counter electrode fabrication. In addition to enhance conversion efficiency, the cells with CNT counter electrode are expected to afford several advantages including nanoscale conducting channels, lightweight, and low cost, as well as improved mechanical properties and thermal stability. The use of a CNT counter electrode in an anthocyanin-sensitized cell showed an efficiency of $1.46 \%$, which is the highest value ever reported compared to a cell using natural dye and platinum counter (Zhu et al., 2008).

Other than solar energy, recent developments in hydrogen storage media have focused on CNTs as one of the ongoing strategic research areas. Hydrogen, a relatively clean fuel compared to conventional fuel, has been considered to be an attractive approach for developing technologies of green energy. The United State Department of Energy (DOE) had targeted minimum hydrogen storage of $6.5 \mathrm{wt} \%$ in order to meet the demand of commercial storage requirement (U.S. Department of
Energy: Washington, 2007). From the investigation on strategies used to achieve hydrogen storage, CNTs have received an exceptional consideration as a potential storage material due to their affordability, recycling characteristics, low density, nanoscale pore size distribution, and reasonable chemical stability (Cheng et al., 2001; Tibbetts et al., 2001; Ritschel et al., 2002). Storage of hydrogen in CNTs mainly involves physiosorption. Theoretical studies conducted by Wang and Johnson (1999) and Dodziuk and Dolgonos (2002) showed that the amount of hydrogen adsorbed depends on the nature of the array and orientation of CNTs, with the adsorption of hydrogen being preferred at the outer surface of CNTs rather than the inner core.

CNTs, particularly SWCNTs, outperform activated carbon for their large bulk density, which enhances volumetric storage. Experimental results (Schur et al., 2002; Furuya et al., 2004; Kayiran et al., 2004; Zhou et al., 2004a; Banerjee and Puri, 2008) indicated that storage of hydrogen in CNTs was lower than $1 \mathrm{wt} \%$ at ambient temperature and high pressure but reasonable storage of hydrogen could be achieved at higher pressure and lower temperature. In fact, hydrogen physiosorption alone was inadequate to meet the DOE specification; hence, research has focused in the direction of hybrid $\mathrm{CNT} /$ metal compounds to promote chemisorption. Transition or alkali metal-doped CNTs, with s-p-d hybridization served to reinforce the notable increase in hydrogen storage via a spill-over mechanism (Yang et al., 2006a; Zacharia et al., 2007). A nearly $30 \%$ increase in hydrogen storage capacity was reported for palladium and vanadium doped CNTs at $2 \mathrm{MPa}$ under room temperature (Zacharia et al., 2005). Schaller et al. (2009) reinforced magnesiumnickel $(\mathrm{Mg}-23.5 \mathrm{wt} \% \mathrm{Ni})$ with $\mathrm{CNT}$ by a powder metallurgy method and reported a hydrogen storage as high as $6.1 \mathrm{wt} \%$. Another research performed by Iyakutti et al. (2009) indicated that CNTs coated 
with aluminum hydride can bind up to four hydrogen molecules, leading to an increase of $8.3 \mathrm{wt} \%$ in hydrogen storage capacity. As an alternative to the metal doping methods, structural defects also appear as another potential approach to enhance chemisorptions of hydrogen in CNTs (Gayathri and Geetha, 2007; Chen and Huang, 2008; He and Pan, 2009; Wang et al., 2009). The existence of structural defects in CNTs can be anticipated with an increase in surface area and pore volume. Such structures definitely enhance the interaction between CNTs and hydrogen, which enables an increase in adsorption binding energy of up to $50 \%$.

Unfortunately, until now, there is controversy, both experimentally and theoretically, surrounding claims that CNTs possess abnormal performance as hydrogen storage since the high storage capacity could not be reproduced by other researchers in the same field (Zhou et al., 2004b). So far, the storage capacity of CNTs still remains far from meeting the DOE target. More efforts are needed in order to prepare CNTs as the base materials for hydrogen storage technology.

\section{Carbon Nanotubes in Supercapacitors}

Electrochemical capacitors or supercapacitors have been considered as an alternative to replace traditional batteries given their miniature size, high power density, long cycle life and high energy density, with potential for reducing waste disposal to the environment. Supercapacitors, as illustrated in Fig. 3, are composed of high surface area activated capacitors that use a molecule-thin layer of electrolyte as dielectric (Capek, 2009).

Recent advancements in nanotechnology have proposed the application of CNTs as electrode material for the capacitor. Utilization of the large surface area of CNTs in the electrode couple with a thinner layer between the electrode and electrolyte enhances the ability of the capacitor to store higher energy densities. Furthermore, the use of vertically aligned CNTs with several atomic diameters in width can significantly increase the supercapacitor capacity and power density as a result of the dramatically increased surface area of the electrode (Hadjipaschalis et al., 2009). Although they possess high surface area, stability and strong mechanical properties, CNTs are not preferable to use alone as the electrode due to their low capacitance (Chou et al., 2008). Therefore, CNTs have been proposed as a substrate for high specific capacitance transition metal oxides such as manganese oxides $\left(\mathrm{MnO}_{2}\right)$ and ruthenium oxide,
$\left(\mathrm{RuO}_{2}\right)$ (Simon and Gogotsi, 2008; Liu et al., 2009a; Yan et al., 2009). Capacitances of approximately $5000 \mathrm{~F}$ have been reported with supercapacitors and energy densities up to $5 \mathrm{Wh} / \mathrm{kg}$, which is about 10 -fold higher than conventional capacitors, with only $0.5 \mathrm{Wh} / \mathrm{kg}$ (Hadjipaschalis et al., 2009).

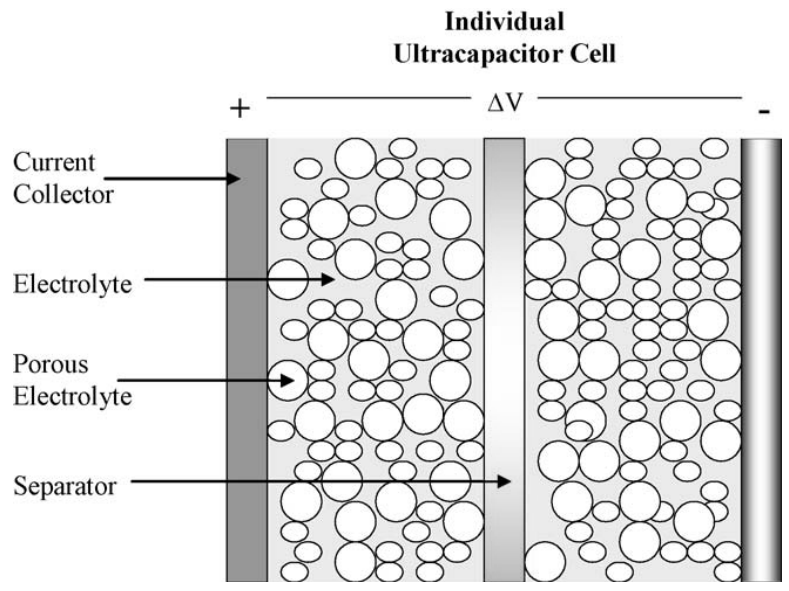

Figure 3: Schematic of a supercapacitor cell. Reprinted from Renewable and Sustainable Energy Reviews, Vol. 13, Hadjipaschalis, I., Poullikkas, A., and Efthimiou, V., Overview of current and future energy storage technologies for electric power applications., Pages No. 1513-1522, (2009), with permission from Elsevier.

\section{Carbon Nanotubes in Green Nanocomposites Design}

Waste generation is proportional to the world's economic growth. Wastes, especially synthetic polymer waste, cause negative impacts on the environment. Thus, as a solution to overcome this problem, the European Community has suggested a waste management concept based on two complementary strategies: avoiding waste by improving product design and increasing the recycling and re-use of waste with an emphasis on life-cycle assessment (LCA) to generate transparent and complete assessments of the environmental impact resulting from all stages of the life cycle of the product or activity in question and to use this to evaluate its environmental attributes (Baillie, 2004).

The future perspective point of view for solving waste disposal issues has driven the challenge to synthesize green nanocomposites by using biodegradable polymers as part of the wave of next generation materials (Mojumdar and Raki, 2005; Wang et al., 2005). The green nanocomposite trend 
employing natural renewable resources embraces the concept of LCA favoring recycling and reuse of waste. Biodegradable polymers have a great potential commercial value and have attracted a great deal of interest from researchers as an alternative to replace non-renewable petroleum-based polymers because of their degradability. However, most of the biodegradable polymers possess poorer mechanical properties and low heat distortion temperatures, which restrict their use in broad applications. Therefore, CNTs could act as nano-reinforcements for the biodegradable polymers in order to provide a suite of composite materials with improvement in mechanical properties, extended durability and better thermal stability. The quality of the biodegradable polymer/CNT nanocomposite is generally determined by the CNT alignment, the CNT-biodegradable polymer adhesion, and the CNT dispersion in the biodegradable polymer matrix (Grossiord et al., 2005; Ray et al., 2006; Vaudreuil et al., 2007).

Song and Qiu (2009) claimed that there was an increase in thermal stability of poly(butylene succinate) (PBSU) by about $10^{\circ} \mathrm{C}$ upon the incorporation with CNTs. Sitharaman et al. (2008) showed that ultra-short CNTs can significantly reinforce poly(propylene fumarate) (PPF), whose inferior mechanical properties often limit its usage in load bearing applications. Apart from this, CNT/PPF nanocomposites exhibit a comparable in vivo biocompatibility that creates the potential for application as a prototype bone tissue engineering scaffold.

Another advantage offered by the green nanocomposites is the ability to recycle the incorporated CNTs due to the degradability of the biodegradable polymer. Degradation of the biodegradable polymer can be achieved through either microbial degradation or enzymatic degradation under specific conditions of $\mathrm{pH}$ and temperature. After degradation, the recovered CNTs may act as reinforcement filler for producing new composites. The reuse and recycling process of CNTs could reduce the waste disposal and, at the same time, be cost effective for material processing.

\section{Carbon Nanotubes in Large Scale Applications}

CNTs have been hailed as promising materials to be applied in various environmental fields. Upon large scale application, there are several issues that must be overcome in order to make them feasible practically.

The high cost of synthesis is always one of the main issues blocking the application of CNTs on a larger scale. However, recent experimental studies have demonstrated the possibility of mass producing high quality CNTs at lower cost (Colomer et al., 2000; Dalton et al., 2004; Agboola et al., 2007). CNTs with a production rate of 595 $\mathrm{kg} / \mathrm{h}$ were reported via decomposition of hydrocarbons by a catalytic chemical vapor deposition (CCVD) method in either a plug flow reactor or a fluidized bed reactor containing a solid catalyst, with an average cost between $\$ 25$ and $\$ 38 / \mathrm{kg}$ (Agboola et al., 2007). Nanothinx, a spin-off company of the Institute of Chemical Engineering and High Temperature Chemical Processes (ICE$\mathrm{HT}$ ), was able to reduce the cost of CNT production by using a low cost novel catalyst developed by them. Studies carried out by Zhang et al. (2007) showed that, by using liquefied petroleum gas (\$400/ton) as carbon source material and the ceramic sphere as substrate, high purity CNTs can be easily produced in large scale at low cost. The possibility of mass production of CNTs has catalyzed the vision to commercialize and apply CNT technology in large scale applications.

Despite the high cost of synthesis, concerns regarding the potential implications of CNTs on the environment and on human health have drawn great attention as well. The widespread applications envisioned for CNTs may lead to their disposal into the environmental compartments of air and water. Through inhalation or via the food chain, disposed CNTs may enter into the human body and result in harmful effects. The harmful effects arise as a function of their physical dimension (Magrez et al., 2006; Wick et al., 2007), physical state (Wick et al., 2007), the presence of impurities (Wick et al., 2007) and chemical treatment (Dumortier et al., 2006; Magrez et al., 2006). In vivo studies of CNTs found that CNTs could induce pulmonary inflammation (Lam et al., 2004) and lung cellular proliferation (Muller et al., 2005) and inhibited the growth of heart muscle $(\mathrm{CBC}, 2007)$ in rats. The toxicity of well dispersed CNTs is less than that of agglomerated CNTs (Wick et al., 2007). Therefore, functionalized CNTs with hydrophilic groups possess less of a toxic impact on mammalian cell viability since their dispersion is improved (Dumortier et al., 2006). This behavior is opposite to what has been observed in bacterial cells, where dispersal increased toxicity (Kang et al., 2008). Up to now, there is still inadequate study regarding the impact of CNTs on the environmental and human health. However, the best way to avoid human and environmental exposure to CNTs is source reduction (Reijnders, 2006). 


\section{CONCLUSIONS}

In this short review, potential proactive to retroactive applications of CNTs in environment systems have been discussed. As a result of theirs excellent mechanical, electrical, physical and chemical properties, CNTs play a major role in waste water treatment and air pollution monitoring. In waste water treatment, CNTs serve as sorbents, nanofilters and antimicrobial agents to remove organic and inorganic contaminants, as well as pathogenic microorganisms. In air pollution monitoring, development of CNT-based gas sensors results in high sensitivity with prompt sensor response toward pollutant gases. In addition, CNTs are also described as one of the key challenges in producing "green" energy, which involves clean combustion. The production of electricity by "green" energy technologies based on biomass catalytic activity (Biofuel cells), renewable sources such as solar (photovoltaic device) and hydrogen (hydrogen fuel cell) prevents the release of toxic gases to the atmosphere and precludes the high demand for fossil fuel. However, these technologies are still not yet been commercially practical because they are still in an emerging stage and more time is required to achieve technical maturation. Apart from this, the superior power density provided by CNT-based supercapacitors has been viewed as an alternative way to replace traditional batteries. Supercapacitors with extended usage time could reduce the amount of waste disposed to the environment over time. Crucial development is still ongoing in order to meet the long term environmental protection challenge. In green materials, the involvement of CNTs in green nanocomposite design embraces the LCA concept, which promotes reduction, reuse and recycle-ability of raw materials. For large scale application, continuous production of CNTs from low-cost sources has taken a closer step to overcoming the problem of the high cost of synthesis. Considering the health implications resulting from widespread use of CNTs, the best way to avoid human and environmental exposure to CNTs is source reduction.

\section{ACKNOWLEDGEMENT}

Financial supports from Universiti Sains Malaysia Research University Grant via Golden Goose project, Ministry of Science, Technology and Innovation (MOSTI), Fundamental Research Grant Scheme (FRGS) and USM Fellowship are gratefully acknowledged.

\section{NOMENCLATURE}

\begin{tabular}{|c|c|}
\hline CNTs & Carbon nanotubes \\
\hline CVD & $\begin{array}{l}\text { Chemical vapor } \\
\text { decomposition }\end{array}$ \\
\hline CCVD & $\begin{array}{l}\text { Catalytic chemical vapor } \\
\text { deposition }\end{array}$ \\
\hline DBP & Disinfection byproducts \\
\hline DSSC & Dye-sensitized solar cells \\
\hline EFC & Enzymatic biofuel cells \\
\hline $\mathrm{LCA}$ & Life-cycle assessment \\
\hline $\mathrm{MFC}$ & Microbial fuel cells \\
\hline MWCNTs & $\begin{array}{l}\text { Multi-walled carbon } \\
\text { nanotubes }\end{array}$ \\
\hline NOx & Nitrogen oxides \\
\hline P3OT & Poly(3-octylthiophene) \\
\hline P3HT & Poly(3-hexylthiophene) \\
\hline PBSU & Poly(butylene succinate) \\
\hline PCBM & $\begin{array}{l}{[6,6] \text {-phenyl- } \mathrm{C}_{61} \text {-butyric }} \\
\text { acid methyl ester }\end{array}$ \\
\hline PEI & Polyethyleneimine \\
\hline PMMA & Poly(methyl methacrylate \\
\hline PPF & Poly(propylene fumarate) \\
\hline SWCNTs & $\begin{array}{l}\text { Single-walled carbon } \\
\text { nanotubes }\end{array}$ \\
\hline UV & Ultraviolet \\
\hline
\end{tabular}

\section{REFERENCES}

Aberle, A. G., Surface passivation of crystalline silicon solar cells: a review. Progress in Photovoltaics: Research and Applications, 8, No. 5, 473 (2000).

Abraham, J. K., Philip, B., Witchurch, A., Varadan, V. K., Reddy, C., A compact wireless gas sensor using a carbon nanotube/PMMA thin film chemiresistor. Smart Materials and Structures, 13, No. 5, 1045 (2004).

Agboola, A. E., Pike, R. W., Hertwig, T. A. and Lou, H. $\mathrm{H}$., Conceptual design of carbon nanotube processes. Clean Technologies and Environmental Policy, 9, No. 4, 289 (2007).

Asuri, P., Bale, S. S., Pangule, R. C., Shah, D. A., Kane, R. S. and Dordick, J. S., Structure, function, and stability of enzymes covalently attached to single-walled carbon nanotubes. Langmuir, 23, No. 24, 12318 (2007).

Asuri, P., Karajanagi, S. S., Yang, H., Yim, T. J., Kane, R. S. and Dordick, J. S., Increasing protein stability through control of the nanoscale environment. Langmuir, 22, No.13, 5833 (2006).

Baillie, C., Green Composites - Polymer Composites and the Environment. CRC Press, New York (2004). 
Balasubramanian, K. and Burghard, M., Chemically functionalized carbon nanotubes. Small, 1, No. 2, 180 (2005).

Banerjee, S. and Puri, I. K., Enhancement in hydrogen storage in carbon nanotubes under modified conditions. Nanotechnology, 19, No. 15, 155702 (2008).

Bethune, D. S., Kiang, C. H., De Vries, M. S., Gorman, G., Savoy, R., Vazquez, J. and Beyers, R., Cobalt-catalysed growth of carbon nanotubes with single-atomic-layer walls. Nature, 363, No. 6430, 605 (1993).

Boehm, H. P., Surface oxides on carbon and their analysis: a critical assessment. Carbon, 40, No. 2, 145 (2002).

Bogue, R. W., Nanotechnology: What are the prospects for sensors?. Sensor Review, 24, No. 3, 253 (2004).

Bohonak, D. M. and Zydney, A. L., Compaction and permeability effects with virus filtration membranes. Journal of Membrane Science, 254, No. 1-2, 71 (2005).

Bondavalli, P., Legagneux, P. and Pribat, D., Carbon nanotubes based transistors as gas sensors: State of the art and critical review. Sensors and Actuators B: Chemical, 140, No. 1, 304 (2009).

Brady-Estévez, A. S., Kang, S. and Elimelech, M., A single-walled-carbon-nanotube filter for removal of viral and bacterial pathogens. Small, 4, No. 4, 481 (2008).

Brown, P., Takechi, K. and Kamat, P. V., Singlewalled carbon nanotube scaffolds for dyesensitized solar cells. Journal of Physical Chemistry C, 112, No. 12, 4776 (2008).

Cantalini, C., Valentini, L., Lozzi, L., Armentano, I., Kenny, J. M. and Santucci, S., $\mathrm{NO}_{2}$ gas sensitivity of carbon nanotubes obtained by plasma enhanced chemical vapor deposition. Sensors and Actuators B: Chemical, 93, No. 1-3, 333 (2003).

Capek, I., Dispersions, novel nanomaterial sensors and nanoconjugates based on carbon nanotubes. Advances in Colloid and Interface Science, 150, No. 2, 63 (2009).

$\mathrm{CBC}$, Bacteria thrive amid carbon nanotubes, study find, CBC News, Toronto, Canada (2007).

Chen, C. H. and Huang, C. C., Enhancement of hydrogen spillover onto carbon nanotubes with defect feature. Microporous and Mesoporous Materials, 109, No. 1-3, 549 (2008).

Cheng, H. M., Yang, Q. H. and Liu, C., Hydrogen storage in carbon nanotubes. Carbon, 39, No. 10, 1447 (2001).

Cho, W. S., Moon, S. I., Paek, K. K., Lee, Y. H., Park, J. H. and Ju, B. K., Patterned multiwall carbon nanotube films as materials of $\mathrm{NO}_{2}$ gas sensors. Sensors and Actuators, B: Chemical, 119, No. 1180 (2006).

Chou, S. L., Wang, J. Z., Chew, S. Y., Liu, H. K. and Dou, S. X., Electrodeposition of $\mathrm{MnO}_{2}$ nanowires on carbon nanotube paper as freestanding. flexible electrode for supercapacitors. Electrochemistry Communications, 10, No. 11, 1724 (2008).

Colomer, J. F., Stephan, C., Lefrant, S., Van Tendeloo, G., Willems, I., Kónya, Z., Fonseca, A., Laurent, C. and Nagy, J. B., Large-scale synthesis of single-wall carbon nanotubes by catalytic chemical vapor deposition (CCVD) method. Chemical Physics Letters, 317, No. 1-2, 83 (2000).

Cortes, P., Deng, S. and Smith, G. B., The adsorption properties of bacillus atrophaeus spores on singlewall carbon nanotubes. Journal of Sensors 2009 (2009).

Dai, H., Rinzler, A. G., Nikolaev, P., Thess, A., Colbert, D. T. and Smalley, R. E., Single-wall nanotubes produced by metal-catalyzed disproportionation of carbon monoxide. Chemical Physics Letters, 260, No. 3-4, 471 (1996).

Dalton, A. B., Collins, S., Razal, J., Munoz, E., Ebron, V. H., Kim, B. G., Coleman, J. N., Ferraris, J. P. and Baughman, R. H., Continuous carbon nanotube composite fibers: Properties. potential applications, and problems, Journal of Materials Chemistry, 14, No. 1, 1 (2004).

Daniel, S., Rao, T. P., Rao, K. S., Rani, S. U., Naidu, G. R. K., Lee, H. Y. and Kawai, T., A review of DNA functionalized/grafted carbon nanotubes and their characterization. Sensors and Actuators, B: Chemical, 122, No. 2, 672 (2007).

Di Francia, G., Alfano, B. and La Ferrara, V., Conductometric gas nanosensors. Journal of Sensors 2009 (2009).

Dodziuk, H. and Dolgonos, G., Molecular modeling study of hydrogen storage in carbon nanotubes. Chemical Physics Letters, 356, No. 1-2, 79 (2002).

Dumortier, H., Lacotte, S., Pastorin, G., Marega, R., Wu, W., Bonifazi, D., Briand, J. P., Prato, M., Muller, S. and Bianco, A., Functionalized carbon nanotubes are non-cytotoxic and preserve the functionality of primary immune cells. Nano Letters, 6, No. 7, 1522 (2006).

Endo, M., Strano, M. and Ajayan, P., Potential Applications of Carbon Nanotubes. Carbon Nanotubes, p. 13 (2008).

Espinosa, E. H., Ionescu, R., Chambon, B., Bedis, G., Sotter, E., Bittencourt, C., Felten, A., Pireaux, J. 
J., Correig, X. and Llobet, E., Hybrid metal oxide and multiwall carbon nanotube films for low temperature gas sensing. Sensors and Actuators, B: Chemical, 127, No. 1, 137 (2007).

Fagan, S. B., Santos, E. J. G., Souza Filho, A. G., Mendes Filho, J. and Fazzio, A., Ab initio study of 2,3,7,8-tetrachlorinated dibenzo-p-dioxin adsorption on single wall carbon nanotubes. Chemical Physics Letters, 437, No. 1-3, 79 (2007).

Fischback, M. B., Jong, K. Y., Zhao, X., Wang, P., Hyun, G. P., Ho, N. C., Kim, J. and Ha, S., Miniature biofuel cells with improved stability under continuous operation. Electroanalysis, 18, No.19-20, 2016 (2006).

Fornasiero, F., Hyung, G. P., Holt, J. K., Stadermann, M., Grigoropoulos, C. P., Noy, A. and Bakajin, O., Ion exclusion by sub-2-nm carbon nanotube pores. Proceedings of the National Academy of Sciences of the United States of America, 105, No. 45, 17250 (2008).

Furuya, Y., Hashishin, T., Iwanaga, H., Motojima, S. and Hishikawa, Y., Interaction of hydrogen with carbon coils at low temperature. Carbon, 42, No. 2, 331 (2004).

Gao, Z., Bandosz, T. J., Zhao, Z., Han, M. and Qiu, J., Investigation of factors affecting adsorption of transition metals on oxidized carbon nanotubes. Journal of Hazardous Materials, 167, No. 1-3, 357 (2009).

Gayathri, V. and Geetha, R., Hydrogen adsorption in defected carbon nanotubes. Adsorption, 13, No. 1, 53 (2007).

Gong, J., Sun, J. and Chen, Q., Micromachined solgel carbon nanotube/ $\mathrm{SnO}_{2}$ nanocomposite hydrogen sensor. Sensors and Actuators, B: Chemical, 130, No. 2, 829 (2008).

Govardhan, C. P., Crosslinking of enzymes for improved stability and performance. Current Opinion in Biotechnology, 10, No. 4, 331 (1999).

Grätzel, M., Dye-sensitized solar cells. Journal of Photochemistry and Photobiology C: Photochemistry Reviews, 4, No. 2, 145 (2003).

Green, M. A., Third generation photovoltaics: Solar cells for 2020 and beyond. Physica E: Lowdimensional Systems and Nanostructures, 14, No. $1-2,65$ (2002).

Grossiord, N., Loos, J. and Koning, C. E., Strategies for dispersing carbon nanotubes in highly viscous polymers. Journal of Materials Chemistry, 15, No. 24, 2349 (2005).

Guo, T., Nikolaev, P., Thess, A., Colbert, D. T. and Smalley, R. E., Catalytic growth of single-walled manotubes by laser vaporization. Chemical Physics Letters, 243, No. 1-2, 49 (1995).
Hadjipaschalis, I., Poullikkas, A. and Efthimiou, V., Overview of current and future energy storage technologies for electric power applications. Renewable and Sustainable Energy Reviews, 13, No. 6-7, 1513 (2009).

He, H. Y. and Pan, B. C., Studies on structural defects in carbon nanotubes. Frontiers of Physics in China, 4, No. 3, 297 (2009).

Hoa, N. D., Quy, N. V., Cho, Y. S. and Kim, D., Nanocomposite of SWNTs and $\mathrm{SnO}_{2}$ fabricated by soldering process for ammonia gas sensor application. Physica Status Solidi (A) Applications and Materials, 204, No. 6, 1820 (2007).

Hsieh, S. H. and Horng, J. J., Adsorption behavior of heavy metal ions by carbon nanotubes grown on microsized $\mathrm{Al}_{2} \mathrm{O}_{3}$ particles. Journal of University of Science and Technology Beijing, Mineral, Metallurgy, Material, 14, No. 1, 77 (2007).

Hummer, G., Rasaiah, J. C. and Noworyta, J. P., Water conduction through the hydrophobic channel of a carbon nanotube. Nature, 414, No. 6860, 188 (2001).

Iijima, S., Helical microtubules of graphitic carbon. Nature, 354, No. 6348, 56 (1991).

International Energy Outlook, U. S., DOE/EIA-0484: Department of Energy Washington, DC (2007).

Iyakutti, K., Kawazoe, Y., Rajarajeswari, M. and Surya, V. J., Aluminum hydride coated singlewalled carbon nanotube as a hydrogen storage medium. International Journal of Hydrogen Energy, 34, No. 1, 370 (2009).

Janssen, R. A. J., Hummelen, J. C. and Sariciftci, N. S., Polymer-fullerene bulk heterojunction solar cells. MRS Bulletin, 30, No. 1, 33 (2005).

Jia, Y., Wei, J., Wang, K., Cao, A., Shu, Q., Gui, X., Zhu, Y., Zhuang, D., Zhang, G., Ma, B., Wang, L., Liu, W., Wang, Z., Luo, J. and Wu, D., Nanotube-silicon heterojunction solar cells. Advanced Materials, 20, No. 23, 4594 (2008).

Jin, S., Fallgren, P. H., Morris, J. M. and Chen, Q., Removal of bacteria and viruses from waters using layered double hydroxide nanocomposites. Science and Technology of Advanced Materials, 8, No. 1-2, 67 (2007).

Journet, C., Maser, W. K., Bernier, P., Loiseau, A., Lamy de la Chapelle, M., Lefrant, S., Deniard, P., Lee, R. and Fischer, J. E., Large-scale production of single-walled carbon nanotubes by the electricarc technique. Nature, 388, No. 6644, 756 (1997).

Kamat, P. V., Meeting the clean energy demand: Nanostructure architectures for solar energy conversion. Journal of Physical Chemistry C, 111, No. 7, 2834 (2007). 
Kang, S., Herzberg, M., Rodrigues, D. F. and Elimelech, M., Antibacterial effects of carbon nanotubes: Size does matter. Langmuir, 24, No. 13, 6409 (2008).

Kang, S., Pinault, M., Pfefferle, L. D. and Elimelech M., Single-walled carbon nanotubes exhibit strong antimicrobial activity. Langmuir, 23, No. 17,8670 (2007).

Kayiran, S. B., Lamari, F. D. and Levesque, D., Adsorption properties and structural characterization of activated carbons and nanocarbons. Journal of Physical Chemistry B, 108, No. 39, 15211 (2004).

Khatri, I., Adhikari, S., Aryal, H. R., Soga, T., Jimbo, $\mathrm{T}$. and Umeno, M., Improving photovoltaic properties by incorporating both single walled carbon nanotubes and functionalized multiwalled carbon nanotubes. Applied Physics Letters, 94, No. 9 (2009).

Kim, J., Jia, H. and Wang, P., Challenges in biocatalysis for enzyme-based biofuel cells. Biotechnology Advances, 24, No. 3, 296 (2006).

Kong, J., Franklin, N. R., Zhou, C., Chapline, M. G., Peng, S., Cho, K. and Dai, H., Nanotube molecular wires as chemical sensors. Science, 287, No. 5453, 622 (2000).

Lam, C. W., James, J. T., McCluskey, R. and Hunter, R. L., Pulmonary toxicity of single-wall carbon nanotubes in mice 7 and 90 days after intractracheal instillation. Toxicological Sciences 77(1): 126-134.(2004)

Landi, B. J., Raffaelle, R. P., Castro, S. L. and Bailey, S. G., Single-wall carbon nanotube-polymer solar cells. Prog. Photovoltaics: Res. Appl, 13, 165 (2005).

Li, Q., Mahendra, S., Lyon, D. Y., Brunet, L., Liga, M. V., Li, D. and Alvarez, P. J. J., Antimicrobial nanomaterials for water disinfection and microbial control: Potential applications and implications. Water Research, 42, No. 18, 4591 (2008a).

Li, X., Zhou, H., Yu, P., Su, L., Ohsaka, T. and Mao, L., A Miniature glucose $/ \mathrm{O}_{2}$ biofuel cell with single-walled carbon nanotubes-modified carbon fiber microelectrodes as the substrate. Electrochemistry Communications, 10, No. 6, 851 (2008b).

Li, Y. H., Wang, S., Wei, J., Zhang, X., Xu, C., Luan, Z., Wu, D. and Wei, B., Lead adsorption on carbon nanotubes. Chemical Physics Letters, 357, No. 3-4, 263 (2002).

Liang, C. W. and Roth, S., Electrical and optical transport of $\mathrm{GaAs} /$ carbon nanotube heterojunctions. Nano Letters, 8, No. 7, 1809 (2008).
Lin, H. F., Ravikrishna, R. and Valsaraj, K. T., Reusable adsorbents for dilute solution separation. 6. Batch and continuous reactors for the adsorption and degradation of 1,2dichlorobenzene from dilute wastewater streams using titania as a photocatalyst. Separation and Purification Technology, 28, No. 2, 87 (2002).

Liu, X., Huber, T. A., Kopac, M. C. and Pickup, P. $\mathrm{G}$, $\mathrm{Ru}$ oxide/carbon nanotube composites for supercapacitors prepared by spontaneous reduction of $\mathrm{Ru}(\mathrm{VI})$ and $\mathrm{Ru}(\mathrm{VII})$. Electrochimica Acta, 54, No. 27, 7141 (2009a).

Liu, Y., Li, Y. and Yan, X. P., Preparation, Characterization, and Application of L-Cysteine Functionalized Multiwalled Carbon Nanotubes as a Selective Sorbent for Separation and Preconcentration of Heavy Metals. Advanced Functional Materials, 18, No. 10, 1536 (2008).

Liu, Y., Lu, S. and Panchapakesan, B., Alignment enhanced photoconductivity in single wall carbon nanotube films. Nanotechnology, 20, No. 3 (2009b).

Logan, B. E., Hamelers, B., Rozendal, R., Schröder, U., Keller, J., Freguia, S., Aelterman, P., Verstraete, W. and Rabaey, K., Microbial fuel cells: Methodology and technology. Environmental Science and Technology, 40, No. 17, 5181 (2006).

Long, R. Q. and Yang, R. T., Carbon Nanotubes as Superior Sorbent for Dioxin Removal. J. Am. Chem. Soc, 123, No. 9, 2058 (2001).

Lu, C. and Chiu, H., Adsorption of zinc(II) from water with purified carbon nanotubes. Chemical Engineering Science, 61, No. 4, 1138 (2006).

$\mathrm{Lu}, \mathrm{C}$. and Chiu, H., Chemical modification of multiwalled carbon nanotubes for sorption of $\mathrm{Zn}^{2+}$ from aqueous solution. Chemical Engineering Journal, 139, No. 3, 462 (2008).

Lu, C., Liu, C. and Rao, G. P., Comparisons of sorbent cost for the removal of $\mathrm{Ni}^{2+}$ from aqueous solution by carbon nanotubes and granular activated carbon. Journal of Hazardous Materials, 151, No. 1, 239 (2008).

Lu, J., Kumar, B., Castro, M. and Feller, J. F., Vapour sensing with conductive polymer nanocomposites (CPC): Polycarbonate-carbon nanotubes transducers with hierarchical structure processed by spray layer by layer. Sensors and Actuators, B: Chemical, 140, No. 2, 451 (2009).

Magrez, A., Kasas, S., Salicio, V., Pasquier, N., Seo, J. W., Celio, M., Catsicas, S., Schwaller, B. and Forró, L., Cellular toxicity of carbon-based nanomaterials. Nano Letters, 6, No. 6, 1121 (2006).

Mauter, M. S. and Elimelech, M., Environmental applications of carbon-based nanomaterials. 
Environmental Science and Technology, 42, No. 16, 5843 (2008).

Mills, A. and Le Hunte, S., An overview of semiconductor photocatalysis. Journal of Photochemistry and Photobiology A: Chemistry, 108, No. 1, 1 (1997).

Minteer, S. D., Liaw, B. Y. and Cooney, M. J., Enzyme-based biofuel cells. Current Opinion in Biotechnology, 18, No. 3, 228 (2007).

Mojumdar, S. C. and Raki, L., Preparation and properties of calcium silicate hydrate-poly(vinyl alcohol) nanocomposite materials. Journal of Thermal Analysis and Calorimetry, 82, No. 1, 89 (2005).

Moon, S. I., Paek, K. K., Lee, Y. H., Park, H. K., Kim, J. K., Kim, S. W. and Ju, B. K., Biasheating recovery of MWCNT gas sensor. Materials Letters, 62, No. 16, 2422 (2008).

Morones, J. R., Elechiguerra, J. L., Camacho, A., Holt, K., Kouri, J. B., Ramírez, J. T. and Yacaman, M. J., The bactericidal effect of silver nanoparticles. Nanotechnology, 16, No. 10, 2346 (2005).

Morozan, A., Stamatin, L., Nastase, F., Dumitru, A., Vulpe, S., Nastase, C., Stamatin, I. and Scott, K., The biocompatibility microorganisms-carbon nanostructures for applications in microbial fuel cells. Physica Status Solidi (A) Applications and Materials, 204, No. 6, 1797 (2007).

Mostafavi, S. T., Mehrnia, M. R. and Rashidi, A. M., Preparation of nanofilter from carbon nanotubes for application in virus removal from water. Desalination, 238, No. 1-3, 271 (2009).

Muller, J., Huaux, F., Moreau, N., Misson, P., Heilier, J. F., Delos, M., Arras, M., Fonseca, A., Nagy, J. B. and Lison, D., Respiratory toxicity of multi-wall carbon nanotubes. Toxicology and Applied Pharmacology, 207, No. 3, 221 (2005).

Nepal, D., Balasubramanian, S., Simonian, A. L. and Davis, V. A., Strong antimicrobial coatings: Single-walled carbon nanotubes armored with biopolymers. Nano Letters, 8, No. 7, 1896 (2008).

Nguyen, H. Q. and Huh, J. S., Behavior of singlewalled carbon nanotube-based gas sensors at various temperatures of treatment and operation. Sensors and Actuators, B: Chemical, 117, No. 2, 426 (2006).

Nguyen, L. H., Phi, T. V., Phan, P. Q., Vu, H. N., Nguyen-Duc, C. and Fossard, F., Synthesis of multi-walled carbon nanotubes for $\mathrm{NH}_{3}$ gas detection. Physica E: Low-dimensional Systems and Nanostructures, 37, No. 1-2, 54 (2007).

Noy, A., Park, H. G., Fornasiero, F., Holt, J. K., Grigoropoulos, C. P. and Bakajin, O., Nanofluidics in carbon nanotubes. Nano Today, 2, No. 6, 22 (2007).

O'Regan, B. and Grätzel, M., A low-cost, highefficiency solar cell based on dye-sensitized colloidal $\mathrm{TiO}_{2}$ films. Nature, 353, No. 6346, 737 (1991).

Palmore, G. T. R. and Whitesides, G. M., Enzymatic conversion of biomass for fuels cells. American Chemical Society, 566, 271 (1994).

Pasquier, A. D., Unalan, H. E., Kanwal, A., Miller, S. and Chhowalla, M., Conducting and transparent single-wall carbon nanotube electrodes for polymer-fullerene solar cells. Appl. Phys. Lett, 87, No. 20, 1 (2005).

Peng, X., Li, Y., Luan, Z., Di, Z., Wang, H., Tian, B. and Jia, Z., Adsorption of 1,2-dichlorobenzene from water to carbon nanotubes. Chemical Physics Letters, 376, No. 1-2, 154 (2003).

Penza, M., Rossi, R., Alvisi, M., Cassano, G. and Serra, E., Functional characterization of carbon nanotube networked films functionalized with tuned loading of $\mathrm{Au}$ nanoclusters for gas sensing applications. Sensors and Actuators, B: Chemical, 140, No. 1, 176 (2009a).

Penza, M., Rossi, R., Alvisi, M., Signore, M. A., Cassano, G., Dimaio, D., Pentassuglia, R., Piscopiello, E., Serra, E. and Falconieri, M., Characterization of metal-modified and verticallyaligned carbon nanotube films for functionally enhanced gas sensor applications. Thin Solid Films, 517, No. 22, 6211 (2009b).

Qi, P., Vermesh, O., Grecu, M., Javey, A., Wang, Q., Dai, H., Peng, S. and Cho, K. J., Toward Large Arrays of Multiplex Functionalized Carbon Nanotube Sensors for Highly Sensitive and Selective Molecular Detection. Nano Lett, 3, No. 3, 347 (2003).

Qiao, Y., Li, C. M., Bao, S. J. and Bao, Q. L., Carbon nanotube/polyaniline composite as anode material for microbial fuel cells. Journal of Power Sources, 170, No. 1, 79 (2007).

Quang, N. H., Van Trinh, M., Lee, B. H. and Huh, J. S., Effect of $\mathrm{NH}_{3}$ gas on the electrical properties of single-walled carbon nanotube bundles. Sensors and Actuators, B: Chemical, 113, No. 1, 341 (2006).

Rao, G. P., Lu, C. and Su, F., Sorption of divalent metal ions from aqueous solution by carbon nanotubes: A review. Separation and Purification Technology, 58, No. 1, 224 (2007).

Ray, S. S., Vaudreuil, S., Maazouz, A. and Bousmina, M., Dispersion of multi-walled carbon nanotubes in biodegradable poly(butylene 
succinate) matrix. Journal of Nanoscience and Nanotechnology, 6, No. 7, 2191 (2006).

Reijnders, L., Cleaner nanotechnology and hazard reduction of manufactured nanoparticles. Journal of Cleaner Production, 14, No. 2, 124 (2006).

Ritschel, M., Uhlemann, M., Gutfleisch, O., Leonhardt, A., Graff, A., Täschner, C. and Fink, J., Hydrogen storage in different carbon nanostructure. Applied Physics Letters, 80, No. 16, 2985 (2002).

Rowell, M. W., Topinka, M. A., McGehee, M. D., Prall, H. J., Dennler, G., Sariciftci, N. S., Hu, L. B. and Gruner, G., Organic solar cells with carbon nanotube network electrodes. Appl. Phys. Lett, 88, No. 23 (2006).

Savage, N. and Diallo, M. S., Nanomaterials and water purification: Opportunities and challenges. Journal of Nanoparticle Research, 7, No. 4-5, 331 (2005).

Sayes, C. M., Liang, F., Hudson, J. L., Mendez, J., Guo, W., Beach, J. M., Moore, V. C., Doyle, C. D., West, J. L., Billups, W. E., Anusman, K. D. and Colvin, V. L., Functionalization density dependence of single-walled carbon nanotubes cytotoxicity in vitro. Toxicology Letters, 161, No. 2, 135 (2006).

Scarselli, M., Scilletta, C., Tombolini, F., Castrucci, P., De Crescenzi, M., Diociaiuti, M., Casciardi, S., Gatto, E. and Venanzi, M., Photon harvesting with multi wall carbon nanotubes. Superlattices and Microstructures, 46, No. 1-2, 340 (2009).

Schaller, R., Mari, D., dos Santos, S. M., Tkalcec, I. and Carreño-Morelli, E., Investigation of hydrogen storage in carbon nanotube-magnesium matrix composites. Materials Science and Engineering A, 521-522, 147 (2009).

Schur, D. V., Tarasov, B. P., Zaginaichenko, S. Y., Pishuk, V. K., Veziroglu, T. N., Shul'ga, Y. M., Dubovoi, A. G., Anikina, N. S., Pomytkin, A. P. and Zolotarenko, A. D., The prospects for using of carbon nanomaterials as hydrogen storage systems. International Journal of Hydrogen Energy, 27, No. 10, 1063 (2002).

Sharma, T., Reddy, A. L. M., Chandra, T. S. and Ramaprabhu, S., Development of carbon nanotubes and nanofluids based microbial fuel cell. International Journal of Hydrogen Energy, 33, No. 22, 6749 (2008).

Sheldon, R. A., Enzyme immobilization: The quest for optimum performance. Advanced Synthesis and Catalysis, 349, No. 8-9, 1289 (2007).

Simon, P. and Gogotsi, Y., Materials for electrochemical capacitors. Nature Materials, 7, No. 11, 845 (2008).
Sitharaman, B., Shi, X., Walboomers, X. F., Liao, H., Cuijpers, V., Wilson, L. J., Mikos, A. G. and Jansen, J. A., In vivo biocompatibility of ultra-short singlewalled carbon nanotube/biodegradable polymer nanocomposites for bone tissue engineering. Bone, 43, No. 2, 362 (2008).

Song, L. and Qiu, Z., Crystallization behavior and thermal property of biodegradable poly(butylene succinate)/functional multi-walled carbon nanotubes nanocomposite. Polymer Degradation and Stability, 94, No. 4, 632 (2009).

Srivastava, A., Srivastava, O. N., Talapatra, S., Vajtai, R. and Ajayan, P. M., Carbon nanotubes filters. Nature Materials, 3, No. 9, 610 (2004).

Stafiej, A. and Pyrzynska, K., Solid phase extraction of metal ions using carbon nanotubes. Microchemical Journal, 89, No. 1, 29 (2008).

Suehiro, J., Zhou, G. and Hara, M., Detection of partial discharge in SF6 gas using a carbon nanotube-based gas sensor. Sensors and Actuators, B: Chemical, 105, No. 2, 164 (2005).

Tahaikt, M., El Habbani, R., Ait Haddou, A., Achary, I., Amor, Z., Taky, M., Alami, A., Boughriba, A., Hafsi, M. and Elmidaoui, A., Fluoride removal from groundwater by nanofiltration. Desalination, 212, No. 1-3, 46 (2007).

Tibbetts, G. G., Meisner, G. P. and Olk, C. H., Hydrogen storage capacity of carbon nanotubes, filaments, and vapor-grown fibers. Carbon, 39, No. 15, 2291 (2001).

Tsai, H. Y., Wu, C. C., Lee, C. Y. and Shih, E. P., Microbial fuel cell performance of multiwall carbon nanotubes on carbon cloth as electrodes. Journal of Power Sources, 194, No. 1, 199 (2009).

Türker, A. R., New Sorbents for Solid-Phase Extraction for Metal Enrichment. CLEAN - Soil, Air, Water, 35, No. 6, 548 (2007).

U.S. Department of Energy: Washington, DC. MultiYear Research, Development, and Demonstration Plan: Planned Program Activities for 2003-2010 (2007).

Ueda, T., Bhuiyan, M. M. H., Norimatsu, H., Katsuki, S., Ikegami, T. and Mitsugi, F., Development of carbon nanotube-based gas sensors for NOx gas detection working at low temperature. Physica E: Low-dimensional Systems and Nanostructures, 40, No. 7, 2272 (2008a).

Ueda, T., Katsuki, S., Takahashi, K., Narges, H. A., Ikegami, T. and Mitsugi, F., Fabrication and characterization of carbon nanotube based high sensitive gas sensors operable at room temperature. Diamond and Related Materials, 17, No. 7-10, 1586 (2008b). 
Ulbricht, R., Lee, S. B., Jiang, X. M., Inoue, K., Zhang, M., Fang, S. L., Baughman, R. H. and Zakhidov, A. A., Transparent carbon nanotube sheets as 3-D charge collectors in organic solar cells. Sol. Energy Mater. Sol. Cells, 91, No. 5, 416 (2007).

Ulbricht, R., Jiang, X., Lee, S.B., Zhang, M., Fang, S., Baughman, R. H., Zakhidov, A., Polymeric solar cells with oriented and strong transparent carbon nanotube anode. Phys. Stat. Sol. B, 243, 3528 (2006).

Valentini, L., Cantalini, C., Armentano, I., Kenny, J. M., Lozzi, L. and Santucci, S., Highly sensitive and selective sensors based on carbon nanotubes thin films for molecular detection. Diamond and Related Materials, 13, No. 4-8, 1301 (2004).

Van Duy, N., Van Hieu, N., Huy, P. T., Chien, N. D., Thamilselvan, M. and Yi, J., Mixed $\mathrm{SnO}_{2} / \mathrm{TiO}_{2}$ included with carbon nanotubes for gas-sensing application. Physica E: Low-dimensional Systems and Nanostructures, 41, No. 2, 258 (2008).

Van Hieu, N., Thuy, L. T. B. and Chien, N. D., Highly sensitive thin film $\mathrm{NH}_{3}$ gas sensor operating at room temperature based on $\mathrm{SnO}_{2} / \mathrm{MWCNTs}$ composite. Sensors and Actuators, B: Chemical, 129, No. 2, 888 (2008).

Vaudreuil, S., Labzour, A., Sinha-Ray, S., Mabrouk, K. E. and Bousmina, M., Dispersion characteristics and properties of poly(methyl methacrylate)/multiwalled carbon nanotubes nanocomposites. Journal of Nanoscience and Nanotechnology, 7, No. 7, 2349 (2007).

Wang, H., Xu, P., Zhong, W., Shen, L. and Du, Q., Transparent poly(methyl methacrylate)/silica/ zirconia nanocomposites with excellent thermal stabilities. Polymer Degradation and Stability, 87, No. 2, 319 (2005).

Wang, J., Liu, L., Cong, S. Y., Qi, J. Q. and Xu, B. $\mathrm{K}$, An enrichment method to detect low concentration formaldehyde. Sensors and Actuators, B: Chemical, 134, No. 2, 1010 (2008).

Wang, Q. and Johnson, J. K., Optimization of carbon nanotube arrays for hydrogen adsorption. Journal of Physical Chemistry B, 103, No. 23, 4809 (1999).

Wang, X., Jialong, L. U. and Xing, B., Sorption of organic contaminants by carbon nanotubes: Influence of adsorbed organic matter. Environmental Science and Technology, 42, No. 9, 3207 (2008).

Wang, Y., Deng, W., Liu, X. and Wang, X., Electrochemical hydrogen storage properties of ball-milled multi-wall carbon nanotubes. International Journal of Hydrogen Energy, 34, No. 3, 1437 (2009).
Watanabe, K., Recent Developments in Microbial Fuel Cell Technologies for Sustainable Bioenergy. Journal of Bioscience and Bioengineering, 106, No. 6, 528 (2008).

Wei, B.Y., Hsu, M. C., Su, P. G., Lin, H. M., Wu, R. J. and Lai, H. J., A novel $\mathrm{SnO}_{2}$ gas sensor doped with carbon nanotubes operating at room temperature. Sensors and Actuators, B: Chemical, 101, No. 1-2, 81 (2004).

Wei, C., Dai, L., Roy, A. and Tolle, T. B., Multifunctional chemical vapor sensors of aligned carbon nanotube and polymer composites. Journal of the American Chemical Society, 128, No. 5, 1412 (2006).

Weng, C. H. and Huang, C. P., Adsorption characteristics of $\mathrm{Zn}$ (II) from dilute aqueous solution by fly ash. Colloids and Surfaces A: Physicochemical and Engineering Aspects, 247, No. 1-3, 137 (2004).

Wick, P., Manser, P., Limbach, L. K., DettlaffWeglikowska, U., Krumeich, F., Roth, S., Stark, W. J. and Bruinink, A., The degree and kind of agglomeration affect carbon nanotube cytotoxicity. Toxicology Letters, 168, No. 2, 121 (2007).

Xie, X. L., Mai, Y. W. and Zhou, X. P., Dispersion and alignment of carbon nanotubes in polymer matrix: A review. Materials Science and Engineering R: Reports, 49, No. 4 (2005).

Xu, D., Tan, X., Chen, C. and Wang, X., Removal of $\mathrm{Pb}(\mathrm{II})$ from aqueous solution by oxidized multiwalled carbon nanotubes. Journal of Hazardous Materials, 154, No. 1-3, 407 (2008).

Yan, J., Fan, Z., Wei, T., Cheng, J., Shao, B., Wang, K., Song, L. and Zhang, M., Carbon nanotube $/ \mathrm{MnO}_{2}$ composites synthesized by microwave-assisted method for supercapacitors with high power and energy densities. Journal of Power Sources, 194, No. 2, 1202 (2009).

Yang, F. H., Lachawiec, Jr. A. J. and Yang, R. T., Adsorption of spillover hydrogen atoms on single-wall carbon nanotubes. Journal of Physical Chemistry B, 110, No. 12, 6236 (2006a).

Yang, K., Zhu, L. and Xing, B., Adsorption of polycyclic aromatic hydrocarbons by carbon nanomaterials. Environmental Science and Technology, 40, No. 6, 1855 (2006b).

Yuan, W., Jiang, G., Che, J., Qi, X., Xu, R., Chang, M. W., Chen, Y., Lim, S. Y., Dai, J. and ChanPark, M. B., Deposition of Silver Nanoparticles on Multiwalled Carbon Nanotubes Grafted with Hyperbranched Poly(amidoamine) and their Antimicrobial Effects. The Journal of Physical Chemistry C, 112, No. 48, 18754 (2008). 
Zacharia, R., Kim, K. Y., Fazle Kibria, A. K. M. and Nahm, K. S., Enhancement of hydrogen storage capacity of carbon nanotubes via spill-over from vanadium and palladium nanoparticles. Chemical Physics Letters, 412, No. 4-6, 369 (2005).

Zacharia, R., Rather, S. U., Hwang, S. W. and Nahm, K. S., Spillover of physisorbed hydrogen from sputter-deposited arrays of platinum nanoparticles to multi-walled carbon nanotubes. Chemical Physics Letters, 434, No. 4-6, 286 (2007).

Zhang, Q., Huang, J., Wei, F., Xu, G., Wang, Y., Qian, W. and Wang, D., Large scale production of carbon nanotube arrays on the sphere surface from liquefied petroleum gas at low cost. Chinese Science Bulletin, 52, No. 21, 2896 (2007).

Zhang, W. D. and Zhang, W. H., Carbon nanotubes as active components for gas sensors. Journal of Sensors 2009 (2009).

Zhao, H. Y., Zhou, H. M., Zhang, J. X., Zheng, W. and Zheng, Y. F., Carbon nanotube-hydroxyapatite nanocomposite: A novel platform for glucose $/ \mathrm{O}_{2}$ biofuel cell. Biosensors and Bioelectronics, 25,
No. 2, 463 (2009).

Zhou, L., Zhou, Y. and Sun, Y., Enhanced storage of hydrogen at the temperature of liquid nitrogen. International Journal of Hydrogen Energy. 29, No. 3, 319 (2004a).

Zhou, L. J., Tan, J. G., Hu, B. H. and Feng, H. L., Ultrastructural study of sclerotic dentin in noncarious cervical lesions disposed by a totaletching dentin adhesive. Journal of Peking University, 36, No. 3, 319 (2004b).

Zhou, M., Deng, L., Wen, D., Shang, L., Jin, L. and Dong, S., Highly ordered mesoporous carbonsbased glucose $/ \mathrm{O}_{2}$ biofuel cell. Biosensors and Bioelectronics, 24, No. 9, 2904 (2009).

Zhu, H., Wei, J., Wang, K. and Wu, D., Applications of carbon materials in photovoltaic solar cells. Solar Energy Materials and Solar Cells, 93, No. 9, 1461 (2009).

Zhu, H. W., Zeng, H. F., Subramanian, V., Masarapu, C., Hung, K. H. and Wei, B. Q., Anthocyanin-sensitized solar cell using carbon nanotube films as counter electrodes. Nanotechnology, 19, No. 46 (2008). 